\title{
MENINGKATKAN PRESTASI BELAJAR SISWA MATA PELAJARAN PKn DENGAN METODE ROLE PLAYING DI SDN IV GUNUNG RAJAK
}

\author{
Ahmad Izzuddin \\ STIT Palapa Nusantara Lombok NTB \\ Email: izzuddinbn@yahoo.co.id
}

\begin{abstract}
This classroom action research aims to improve student achievement by applying role playing method in civic education education material impact of globalization. There are several problems found in the field observation, among others, the low achievement of students in civic education learning (Civics) with several factors that influence, among others, from students, families, material understanding, teachers and the use of teaching aids. Furthermore, by using the role playing method, the writer found a good learning achievement change that is from the result of data analysis of student's learning skill in class, reaching the average value of cycle class $I$ is 67,50 and on second cycle equal to 77,50 and increase as big as 10.00, with completeness level in cycle I equal to $65,55 \%$. In the second cycle of $95.45 \%$ Achievement of power seraf in cycle I $73.82 \%$, the second cycle of $79.52 \%$ so that an increase of $5.70 \%$
\end{abstract}

Keyword: Student Learning Achievement, Role Playing Method 


\begin{abstract}
Abstrak: Penelitian tindakan kelas ini bertujuan meningkatkan prestasi siswa dengan penerapan metode role playing dalam pembelajaran pendidikan kewarganegaraan materi dampak globalisasi. Ada beberapa persoalan yang ditemukan dalam pengamatan sementara di lapangan antara lain, rendahnya prestasi siswa dalam pembelajaran pendidikan kewarganegaraan (PKn) dengan beberapa faktor yang mempengaruhi antara lain, dari siswa, keluarga, pemahaman materi, guru dan penggunaan alat bantu pembelajaran. Selanjutnya, dengan menggunakan metode role playing, penulis menemukan perubahan prestasi belajar yang baik yaitu dari hasil analisis data keterampilan belajar siswa didalam kelas, nilai ratarata kelas siklus I sebesar 67,50 dan pada siklus II sebesar 77,50 dan mengalami peningkatan sebesar 10,00, dengan taraf ketuntasan pada siklus I sebesar 65,55\%. Pada siklus II sebesar 95,45\% Pencapaian daya seraf pada siklus I 73,82\%, siklus II sebesar 79,52\% sehingga mengalami peningkatan sebesar 5,70\%.
\end{abstract}

Kata kunci: Prestasi Belajar Siswa, Metode Role Playing

\title{
Pendahuluan
}

Kemajuan Ilmu pengetahuan dan teknologi turut mewarnai dunia pendidikan kita saat ini. Tantangan tentang peningkatan mutu, relevansi dan efektivitas pendidikan sebagai tuntutan nasional sejalan dengan perkembangan dan kemajuan masyarakat, berimplikasi secara nyata dalam program pendidikan dan kurikulum sekolah. Tujuan dari program kurikulum adalah dapat tercapai dengan baik,mdengan jalan program di desain secara jelas dan aplikatif sesuai dengan kebutuhan dan kondisi pendidikan masyarakat di Indonesia.

Hubungannya dengan itu, guru dituntut untuk memiliki kemampuan mendesain programnya dan sekaligus menentukan strategi intruksional yang harus ditempuh. Para

1 Hingga saat ini, kurikulum yang digunakan adalah kurikum 13, K13 bertujuan untuk memudahkan proses belajar dan mengajar didalam kelas, dapat menginternalisasi ilmu-ilmu pengetahuan, sesuai dengan bidang yang diminati, baik pengetahuan yang yang bersifat keagamaan dan non keagamaan, ilmu eksat, sains dan sebagainya. Selain itu, dalam isi dan kandungannya K13 ini mencoba untuk merelevansikan dan menyusuaikan pengetahuanpengetahuan yang masuk melalui leraning by doing, leraning by to do, learning by writing. Dan leraning by experiences terhadap kondisi pendidikan masyarakat Indonesia yang notabene masyarakat kultural. Lihat Abdul Haris Rasyidi, Meningkatkan Hasil Belajar Bahasa Arab dalam Materi Hiwar Melalui Strategi Pembelajaran Cooperative Learning Tipe Probelm Posing MTs NW Selebung Ketangga, Skripsi Ilmiah, tidak dipulikasikan, 2012, 1. 
guru harus memiliki keterampilan memilih dan menggunakan metode dan strategi mengajar yang diterapkan dalam sistem pembelajaran yang efektif. ${ }^{2}$

Sekolah Dasar adalah lembaga pendidikan formal yang mempersiapkan siswa untuk menjadi anggota masyarakat yang memiliki karakter dan kepribadian baik, dan memiliki kemampuan menganal diri mereka sendiri dan hal-hal yang ada di alam.

Berdasarkan uraian di atas, maka peran pendidikan menjadi sangat penting. Pendidikan seharusnya dapat mempersiapkan siswa untuk dapat bersaing di era global dan masyarakat ekonomi ASEAN (MEA). Oleh sebab itu, pendidikan perlu direkonstruksi ulang agar menghasilkan output pendidikan yang siap menghadapi perkembangan kehidupan dan ikut mengaktualisasikan perannya di masa-masa mendatang. ${ }^{3}$ Berdasarkan data yang ditemukan oleh peneliti di lapangan, Siswa kelas IV Sekolah Dasar Negeri 4 Gunung Rajak sebagian besar memperoleh nilai dan hasil belajar di bawah standar ketuntasan minimal pada mata pelajaran Pendidikan Kewarganegaraan materi dampak globalisasi. Keadaan ini merupakan beban bagi guru mata pelajaran yang harus segera dituntaskan. Penulis akan mencoba menggunakan metode role playing pada mata pelajaran Pendidikan Kewarganegaraan materi dampak globalisasi pada siswa kelas IV Sekolah Dasar Negeri 4 Gunung Rajak. Hal ini terjadi karena banyak faktor yang mempengaruhi prestasi siswa antara lain adalah: kepribadian siswa seperti kurang minat belajar, suka bermain didalam kelas, membeli mainan untuk dibawa keruang kelas. Faktor rumah tangga seperti broked home sehingga mereka terpaksa harus tinggal bersama nenek, bibi atau keluarga yang lain.

Dalam hal ini tentunya anak menjadi korban ketidakdilan, sehingga pendidkannya kurang mendapatkan perhatian, sebagaimana ketika mereka masih memiliki keluarga yang harmonis dan utuh. Sedangkan yang lain adalah faktor lingkungan, rata-rata siswa bertempat tinggal di perkampungan yang notabene bukan merupakan lingkungan belajar. Selanjutnya, guru sendiri masih menggunakan kegiatan

2 Agus Suprijono, Cooperative learning: Teori dan Apliksai Paikem, (Yogyakarta: Pustaka Pelajar, 2009), 45.

${ }^{3}$ Suharsimi Arikunto, Prosedur Penelitian: Suatu Pendekatan Praktik, (Jakarta: Renika Cipta, 2006), 15. 
pembelajaran yang bersifat monoton, dalam arti yaitu perlu pembenahan dan perbaikan metode-metode belajar yang representatif, serta penggunaan alat bantu pelajaran yang terabaikan. Keadaan seperti ini tentunya sangat rentan mempengaruhi prestasi siswa di Sekolah Dasar Negeri 4 Gunung Rajak.

Tugas dan fungsi guru sangat dituntut untuk mengatasi masalah yang menjadi kendala di sekolahnya. Terdapat banyak cara yang bisa digunakan antara lain mengganti metode pembelajarannya, memilih strategi dan model pembelajaran yang menarik serta sesuai dengan materi yang akan diajarkan.

\section{Tujuan Penelitian}

Penelitian ini bertujuan untuk meningkatkan prestasi belajar siswa dalam memahami dampak globalisasi serta siswa mengetahui penerapan dampak tersebut dalam kehidupan sehari-hari. Disamping itu, siswa mengetahui perubahan yang terjadi sebagai dampak globalisasi baik dampak positif maupun dampak negatif dalam bidang komunikasi, transportasi dan gaya hidup masyarakat modern.

\section{Kajian Teori}

Benyamin S.Bloom menyatakan "Prestasi merupakan hasil perubahan tingkah laku yang meliputi ranah kognitif terdiri atas: pemahaman, pengetahuan, aplikasi, analisis, sintesis dan evaluasi”. Adapun faktor - faktor yang mempengaruhi prestasi belajar yaitu: ${ }^{4}$

Pertama, Faktor internal adalah faktor yang berasal dari individu anak itu sendiri yang meliputi :

a. Faktor jasmaniah (pisiologis), yang termasuk didalamnya antara lain: penglihatan, pendengaran, struktur tubuh dan sebagainya.

b. Faktor psikologis, termasuk didalamnya: Intelektual (taraf intelegensi, kemampuan belajar dan cara belajar).

c. Non Intelektual (motivasi belajar, sikap, minat, perasaan, kondisi psikis, dan kondisi akibat keadaan sosiokultur).

${ }^{4}$ Husnul Chotimah, Yuyun Dwitasari, Strategi-strategi Pembelajaran Untuk Penelitian Tindakan Kelas, (Malang: Surya Pena Gemilang, 2009), 56. 
Faktor kondisi fisik.

Faktor eksternal, adalah faktor dari luar seperti:

a. Faktor pengaturan belajar disekolah (kurikulum, disiplin sekolah, guru, pasilitas belajar, dan pengelompokan siswa)

b. Faktor sosial disekolah (system social, status sosial siswa, serta interaksi guru dan siswa)

c. Faktor situasional (keadan politik, ekonomi, keadaan waktu dan tempat atau iklim)

Dari uraian diatas tentang prestasi belajar dan faktor yang mempengaruhinya bahwa pengertian prestasi belajar ialah hasil usaha bekerja atau belajar yang menunjukkan ukuran kecakapan yang dicapai dalam bentuk nilai. Menurut Jill Hadfield, "Role playing atau bermain peran adalah sejenis permainan gerak yang didalamnya ada tujuan, aturan dan sekaligus melibatkan unsur senang. Dalam role playing murid dikondisikan pada situasi tertentu di luar kelas, meskipun saat itu pembelajaran terjadi di dalam kelas. Selain itu, role playing sering kali dimaksudkan sebagai suatu bentuk aktivitas dimana pembelajar membayangkan dirinya seolah-olah berada di luar kelas dan memainkan peran orang lain". 5

Pada metode bermain peranan, titik tekanannya terletak pada keterlibatan emosional dan pengamatan indera ke dalam suatu situasi masalah yang secara nyata dihadapi. Murid diperlakukan sebagai subyek pembelajaran, secara aktif melakukan praktik-praktik berbahasa (bertanya dan menjawab) bersama teman-temannya pada situasi tertentu. Belajar efektif dimulai dari lingkungan yang berpusat pada diri murid. Lebih lanjut prinsip pembelajaran memahami kebebasan berorganisasi, dan menghargai keputusan bersama, murid akan lebih berhasil jika mereka diberi kesempatan memainkan peran dalam bermusyawarah, melakukan pemungutan suara terbanyak dan bersikap mau menerima kekalahan sehingga dengan melakukan berbagai kegiatan tersebut dan secara aktif berpartisipasi, mereka akan lebih mudah menguasai apa yang mereka pelajari.

5 Slavin, E Robert, Educational Psychology Theory dan Practice, Fifth Edition, (Allyn and Succon, 1997), 153. 
Langkah-langkah pembelajarannya adalah sebagai berikut :

a. Gruru menyusun/menyiapkan skenario yang akan ditampilkan.

b. Menunjuk beberapa siswa untuk mempelajari skenario dalam waktu beberapa hari sebelum pelaksanaan Kegiatan Belajar Mengajar.

c. Guru membentuk kelompok siswa yang anggotanya 5 orang.

d. Memberikan penjelasan tentang kompetensi yang ingin dicapai.

e. Memanggil para siswa yang sudah ditunjuk untuk melakonkan skenario yang sudah dipersiapkan.

f. Masing-masing siswa berada di kelompoknya sambil mengamati skenario yang sedang diperagakan.

g. Setelah selesai ditampilkan, masing-masing siswa diberikan lembar kerja untuk membahas/memberi penilaian atas penampilan masing-masing kelompok.

h. Masing-masing kelompok menyampaikan hasil kesimpulannya.

i. Guru memberikan kesimpulan secara umum.

j. Evaluasi.

k. Penutup

\section{Keunggulan Metode Role Playing}

Ada beberapa keunggulan dengan menggunakan metode role playing, di antaranya adalah:

1. Dapat berkesan dengan kuat dan tahan lama dalam ingatan siswa. Disamping merupakan pengalaman yang menyenangkan yang sulit untuk dilupakan.

2. Sangat menarik bagi siswa, sehingga memungkinkan kelas menjadi dinamis dan penuh antusias.

3. Membangkitkan gairah dan semangat optimisme dalam diri siswa serta menumbuhkan rasa kebersamaan.

4. Siswa dapat terjun langsung untuk memerankan sesuatu yang akan di bahas dalam proses belajar. ${ }^{6}$

${ }^{6}$ Hamalik, Oemar, Strategi Belajar Mengajar Berdasarkan CBSA, (Bandung: Sinar Baru Algensido, 2009), 4. 


\section{Kelemahan Metode Role Playing}

Disamping memiliki keunggulan, metode role playing juga memiliki kelemahan, di antaranya adalah :

1. Bermain peran memakan waktu yang banyak.

2. Siswa sering mengalami kesulitan untuk memerankan peran secara baik khususnya jika mereka tidak diarahkan atau tidak ditugasi dengan baik. Siswa perlu mengenal dengan baik apa yang akan diperankannya.

3. Bermain peran tidak akan berjalan dengan baik jika suasana kelas tidak mendukung.

4. Jika siswa tidak dipersiapkan dengan baik ada kemungkinan tidak akan melakukan secara sungguh-sungguh.

5. Tidak semua materi pelajaran dapat disajikan melalui metode ini. ${ }^{7}$

\section{Kerangka Berfikir}

Latar belakang penelitian ini adalah rendahnya prestasi siswa pada mata pelajara PKn materi dampak globalisasi pada siswa kelas IV SDN 4 Gunung Rajak semester II TP. 2016/2017. Prestasi, prilaku dan pemahaman konsep siswa sebelumnya secara klasikal berada pada rata-rata 62,21 dengan tingkat ketuntasn 45,00\%. Untuk meningkatkan prestasi siswa peneliti menggunakan penerapan metode role playing. Penelitian ini dilaksanakan sebanyak dua siklus, masing-masing siklus menggunakan 4 tahapan yaitu tahap perencanaan,tindakan ,observasi dan refleksi.

Dari hasil perolehan di siklus I nilai rata-rata siswa sebesar 67,50 dengan tingkat ketuntasan 100\% dan pada siklus II ada peningkatan menjadi rata-rata 77,50 dengan tingkat ketuntasan 100\%..Jadi dapat disimpulkan bahwa penggunaan method role playing pada kegiatan pembelajaran ini terbukti dapat meningkatkan prestasi belajar siswa.

${ }^{7}$ Ibid. 


\section{Tekhnik Penelitian.}

Salah satu cara yang digunakan peneliti dalam penelitian ini yaitu tekhnik test yaitu dalam bentuk tes subyektif dengan jenis tes tertulis dan macam tes pilihan ganda dan menjodohkan (matching tets).

\section{Hasil dan Pembahasan}

Data yang telah dikumpulkan baik pada siklus I dan pada siklus II hanyalah merupakan data atau informasi mentah yang masih perlu di analisis. Hasil penelitian yang dikemukakan disini mencakup penelitian pada siklus I dan siklus II dengan materi pengaruh globalisasi dengan metode pembelajaran role playing. Hasil tersebut meliputi ketrampilan unjuk kerja, perilaku dan peningkatan prestasi pada siswa kelas IV SDN 4 desa Pandan Wangi kecamatan .

Adapun langkah-langkah yang ditempuh dalam analisis data dalam penelitian ini akan dijabarkan secara berturut-turut sebagai berikut :

\section{Deskripsi Kondisi Awal.}

Pelaksanaan kegiatan pembelajaran di SD Negeri 4 Gunung Rajak lebih banyak menggunakan tekhnik konvensional. Hal ini menyebabkan kurangnya minat belajar siswa, sering keluar masuk kelas dengan berbagai macam alasan, ada siswa yang acuh dengan tugas yang diberikan guru, suka mencontek pekerjaan temannya, dan bermacam masalah lain yang terjadi, sehingga perlu diadakan penelitian.

Penelitian yang dilaksanakan ini berdasarkan kondisi yang terjadi di SD Negeri 4 Gunung Rajak dengan latar belakang yaitu rendahnya prestasi siswa terhadap materi dampak globalisasi mata pelajaran pendidikan Kewarganegaraan dan tidak terdukungnya proses pembelajaran dengan metode serta alat yang disesuikan dengan materi ajar. Hal lain yang sangat mempengaruhi juga datang dari kepribadian siswa yang berbeda-beda, dan kurang mendapat dukungan dari keluarga maupun lingkungan.

Dengan diterapkannya metode role playing dalam pembelajaran ini diharapkan dapat menjadi solusi dalam meningkatkan prestasi siswa khususnya di kelas IV SD Negeri 4 Gunung Rajak. 


\section{Deskripsi Analisis Hasil Penelitian Tindakan Siklus I Perencanaan Tindakan}

Sesuai dengan rencana tindakan yang telah ditetapkan dalam siklus I dengan menerapkan metode role playing,dengan materi pembelajaran dampak globalisasi kompetens idasar, memberikan contoh sederhana pengaruh glbalisasi di lingkungannya.Dalam penelitian ini indikator yang digunakan untuk menentukan hasiltes pengetahuan siswa dalam pembelajaran dibatasi pada beberapa aspek. .Aspek yang dimaksud adalah keaktifan belajar siswa, perilaku siswa dan pemahaman konsep pengaruh globalisasi dimana penilaiannya diambil melalui observasi kegiatan pembelajara menggunakan metode rle playing dan tes tertulis.

\section{Pelaksanaan Tindakan.}

Pada tahap pelaksanaan kegiatan pembelajaran PKn dengan menerapkan model pembelajaran Role Playing meliputi beberapa tahap sebagai berikut:

1. Kegiatan Awal

a. Guru mengkondisikan kelas untuk memulai kegiatan pembelajaran.

b. Guru menyampaikan apersepsi: memotivasi, dan menjelaskan tujuan pembelajaran yang akan dicapai melalui kegiatan pembelajaran role playing.

b. Guru memotivasi siswa untuk belajar dengan mengaitkan materi yang akan dipelajari dengan materi yang telah lalu.

2. Kegiatan Inti:

a. Guru memberikan penjelasan tentang materi Dampak Globalisasi.Pada tahap ini siswa dihadapkan pada sesuatu yang menimbulkan kebingungan dan dirangsang untuk melakukan kegiatan bermain peran guna menjawab kebingungan tersebut.

b. Guru memberi kesempatan kepada peserta didik untuk mengidentifikasi sebanyak mungkin masalah yang relevan dengan bahan pelajaran kemudian salah satunya dipilih dan dirumuskan dalam bentuk bermain peran.

c. Ketika eksplorasi berlangsung, guru memberi kesempatan kepada para peserta didik untuk mengumpulkan informasi 
sebanyak-banyaknya yang relevan untuk membuktikan benar atau tidaknya hipotesis.

a. Kemudian guru mengolah data dan informasi yang telah diperoleh para peserta didik baik melalui wawancara, observasi, dan sebagainya.

b. Siswa melakukan pemeriksaan secara cermat untuk membuktikan benar atau tidaknya hipotesis yang ditetapkan dengan temuan alternative dihubungkan dengan hasil pengolahan data.

c. Siswa menarik kesimpulan yang dapat dijadikan prinsip umum dan berlaku untuk semua kejadian atau masalah yang sama dengan memperhatikan hasil pembuktian.

d. Guru member penguatan dan member motivasi kepada siswa agar lebih berani dalam mengutarakan pendapatnya.

e. Siswa diberi kesempatan untuk bertanya tentang materi yang belum dipahami.

f. Guru membagikan soal tes formatif mengenai materi yang telah diberikan.

3. Kegiatan Akhir

a. Guru bersama-sama siswa menyimpulkan materi yang telah dipelajari.

b. Guru memberikan motivasi kepada siswa agar selalu rajin belajar.

c. Guru memberikan tindak lanjut berupa PR untuk mengetahui tingkat kepahaman siswa.

d. Sebelum mengakhiri pembelajaran, guru mengajak para siswa berdoa sebagai penutup pembelajaran hari ini.

Data hasil prestasi belajar siswa dapat dilihat dalam table berikut ini :

Tabel 1.1 Perolehan/prestasi belajar pada siklus I

\begin{tabular}{|l|l|l|l|l|l|l|}
\hline $\mathbf{N}$ & NAMA & ANALISIS HASIL & $\mathbf{S}$ & $\mathbf{N E T}$ & K \\
$\mathbf{0}$ & SISWA & & $\mathbf{K}$ & $\mathbf{\text { UN }}$ & E \\
& & $\mathbf{0}$ & $\mathbf{A}$ & TAS & T. \\
\hline
\end{tabular}




\begin{tabular}{|c|c|c|c|c|c|c|c|c|c|c|c|c|c|c|c|c|c|c|c|c|c|c|c|c|c|}
\hline & & & & & & & & & & & & & & & & & & & & & & $\mathbf{R}$ & & $\mathrm{Al}$ & \\
\hline & & 1 & 2 & 3 & 4 & 5 & 6 & 7 & 8 & 9 & $\begin{array}{l}1 \\
0\end{array}$ & $\begin{array}{l}1 \\
1\end{array}$ & $\begin{array}{l}1 \\
2\end{array}$ & $\begin{array}{l}1 \\
3\end{array}$ & $\begin{array}{l}1 \\
4\end{array}$ & $\begin{array}{l}1 \\
5\end{array}$ & $\begin{array}{l}1 \\
6\end{array}$ & $\begin{array}{l}1 \\
7\end{array}$ & $\begin{array}{l}1 \\
8\end{array}$ & $\begin{array}{l}1 \\
9\end{array}$ & $\begin{array}{l}2 \\
0\end{array}$ & & & & $\begin{array}{l}\mathrm{T} \\
\mathrm{D} \\
\mathrm{K}\end{array}$ \\
\hline 1 & $\begin{array}{l}\text { Ahmad } \\
\text { Amtohyi }\end{array}$ & 1 & 1 & 1 & 1 & 1 & 0 & 0 & 1 & 1 & 1 & 1 & 0 & 1 & 1 & 1 & 1 & 1 & 0 & 0 & 0 & $\begin{array}{l}1 \\
4\end{array}$ & $\begin{array}{l}7 \\
0\end{array}$ & $\sqrt{1}$ & \\
\hline 2 & $\begin{array}{l}\text { Ahmad } \\
\text { Riandi }\end{array}$ & 0 & 1 & 1 & 1 & 1 & 0 & 0 & 1 & 1 & 1 & 1 & 0 & 1 & 1 & 1 & 1 & 1 & 0 & 0 & 0 & $\begin{array}{l}1 \\
3\end{array}$ & $\begin{array}{l}6 \\
5\end{array}$ & & $\checkmark$ \\
\hline 3 & $\begin{array}{l}\text { Aidil Majdi } \\
\text { Azrori }\end{array}$ & 0 & 0 & 0 & 0 & 1 & 1 & 1 & 1 & 1 & 1 & 1 & 0 & 1 & 1 & 0 & 1 & 1 & 1 & 0 & 0 & $\begin{array}{l}1 \\
3\end{array}$ & $\begin{array}{l}6 \\
5\end{array}$ & & $\checkmark$ \\
\hline 4 & $\begin{array}{l}\text { Antoni } \\
\text { Saputra }\end{array}$ & 0 & 1 & 1 & 1 & 1 & 0 & 1 & 1 & 1 & 1 & 1 & 1 & 0 & 1 & 0 & 0 & 0 & 0 & 1 & 0 & $\begin{array}{l}1 \\
2\end{array}$ & $\begin{array}{l}6 \\
0\end{array}$ & & $\checkmark$ \\
\hline 5 & Azlina Fitri & 1 & 1 & 1 & 1 & 1 & 0 & 1 & 1 & 1 & 1 & 1 & 0 & 1 & 0 & 0 & 1 & 0 & 0 & 0 & 0 & $\begin{array}{l}1 \\
2\end{array}$ & $\begin{array}{l}6 \\
0\end{array}$ & & $\checkmark$ \\
\hline 6 & $\begin{array}{l}\text { Baiq } \\
\text { Silaturrahmi }\end{array}$ & 0 & 1 & 0 & 1 & 1 & 1 & 1 & 1 & 0 & 0 & 1 & 1 & 0 & 0 & 0 & 0 & 1 & 1 & 1 & 0 & $\begin{array}{l}1 \\
1\end{array}$ & $\begin{array}{l}5 \\
5\end{array}$ & & $\checkmark$ \\
\hline 7 & $\begin{array}{l}\text { Bunga } \\
\text { Ulandari }\end{array}$ & 1 & 1 & 0 & 0 & 1 & 1 & 1 & 1 & 0 & 1 & 1 & 1 & 1 & 1 & 0 & 1 & 1 & 1 & 0 & 0 & $\begin{array}{l}1 \\
4\end{array}$ & $\begin{array}{l}7 \\
0\end{array}$ & $\sqrt{ }$ & \\
\hline 8 & $\begin{array}{l}\text { Depiana } \\
\text { Lestari }\end{array}$ & 1 & 1 & 1 & 1 & 1 & 0 & 1 & 1 & 0 & 1 & 1 & 0 & 1 & 1 & 0 & 1 & 0 & 0 & 0 & 1 & $\begin{array}{l}1 \\
3\end{array}$ & $\begin{array}{l}6 \\
5\end{array}$ & & $\checkmark$ \\
\hline 9 & $\begin{array}{l}\text { FadilahOlya } \\
\text { Suganda }\end{array}$ & 0 & 0 & 1 & 1 & 1 & 0 & 1 & 1 & 1 & 1 & 1 & 1 & 1 & 1 & 1 & 1 & 0 & 1 & 1 & 1 & $\begin{array}{l}1 \\
6\end{array}$ & $\begin{array}{l}8 \\
0\end{array}$ & $\checkmark$ & \\
\hline 10 & Fuji Salwati & 0 & 0 & 1 & 1 & 1 & 1 & 1 & 1 & 1 & 0 & 0 & 1 & 0 & 1 & 0 & 1 & 0 & 1 & 0 & 1 & $\begin{array}{l}1 \\
2\end{array}$ & $\begin{array}{l}6 \\
0\end{array}$ & & $\checkmark$ \\
\hline 11 & Ikhsan Jayadi & 0 & 0 & 0 & 0 & 1 & 1 & 1 & 1 & 1 & 1 & 1 & 0 & 0 & 0 & 0 & 0 & 1 & 0 & 1 & 1 & $\begin{array}{l}1 \\
0\end{array}$ & $\begin{array}{l}5 \\
0\end{array}$ & & $\checkmark$ \\
\hline 12 & $\begin{array}{l}\text { Inayatul } \\
\text { Wahidah }\end{array}$ & 1 & 1 & 1 & 1 & 1 & 0 & 1 & 1 & 0 & 1 & 1 & 0 & 1 & 1 & 1 & 1 & 0 & 0 & 0 & 0 & $\begin{array}{l}1 \\
3\end{array}$ & $\begin{array}{l}6 \\
5\end{array}$ & & $\checkmark$ \\
\hline
\end{tabular}




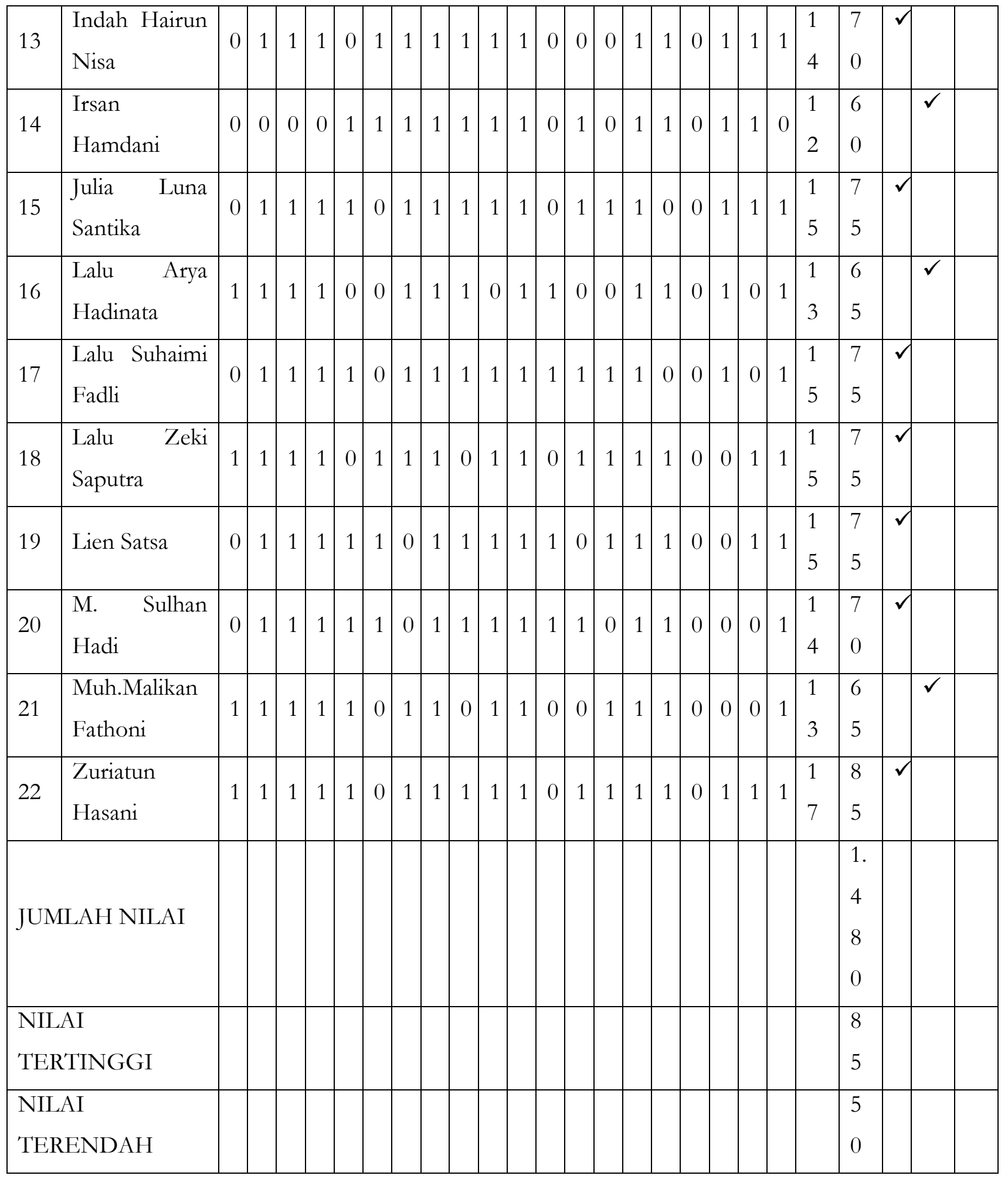




waw

Tabel 1.2.Hasil pengamatan proses pembelajaran

\begin{tabular}{|l|l|l|l|l|l|l|}
\hline No & Kegiatan yang diamati & \multicolumn{2}{l|}{ Skor } & \multicolumn{2}{l|}{ Ket. } \\
\hline & & 4 & 3 & 2 & 1 & \\
\hline 1. & Mempersiapkan siswa untuk belajar & $\checkmark$ & & & & \\
\hline 2 & Melakukan kegiatan apersepsi & $\checkmark$ & & & & \\
\hline 3 & Menguasai materi pembelajaran & $\checkmark$ & & & & \\
\hline 4 & $\begin{array}{l}\text { Menyampaikan materi dengan jelas sesuai dengan } \\
\text { hierarki belajar dan karakteristik siswa }\end{array}$ & $\checkmark$ & & & & \\
\hline 5 & Mengaitkan materi dengan realitas kehidupan & $\checkmark$ & & & & \\
\hline 6 & $\begin{array}{l}\text { Menggunakan metode role playing dan membagi } \\
\text { kelompok siswa }\end{array}$ & $\checkmark$ & & & & \\
\hline 7 & $\begin{array}{l}\text { Menumbuhkan partisifasi aktif siswa dalam } \\
\text { kegiatan bermain peran/ role playing }\end{array}$ & $\checkmark$ & & & & \\
\hline 8 & $\begin{array}{l}\text { Menumbuhkan keceriaan dan antusias siswa dalam } \\
\text { belajar }\end{array}$ & $\checkmark$ & & & & \\
\hline 9 & $\begin{array}{l}\text { Memantau kemajuan belajar selama proses } \\
\text { pembelajaran }\end{array}$ & & & & & \\
\hline 10 & $\begin{array}{l}\text { Mempersilahkan kelompok lain memberikan } \\
\text { tanggapan }\end{array}$ & & & & & \\
\hline 13 & Melakukan refleksi & & & & \\
\hline
\end{tabular}

Gunung Rajak, 11 Maret 2017, Observer Hapiz Bisri. 


\section{Observasi}

Berdasarkan hasil analisis data hasil tes siswa yang dianalisis selama siklus I, skor rata-rata siswa sebesar 67,50.Berdasarkan kriteria klasifikasi keterampilan belajar yang telah ditetapkan diperoleh bahwa aktivitas belajar siswa selama pembelajaran pada siklus I tergolong cukup baik, dengan tingkat ketuntasan 65,55 \%.

Sedangkan hasil observasi terhadap pelaksanaan pembelajaran pada siklus I yang menerapkan metode role playing dapat digambarkan dari hasil observasi yang dilakukan oleh teman sejawat terhadap pelaksanaan pembelajaran dikelas IV Sekolah Dasar Negeri 4 Gunung Rajak dimana efektifitas penggunaan metode tersebut terbukti dapat meningkatkan hasil belajar siswa atau prestasi siswa .

\section{Refleksi}

Berdasarkan temuan pada siklus I yang menyangkut hasil observasi, hasil belajar siswa mencapai ketuntasan 65,55 \% dengan katagori baik, artinya maka dapat disimpulkan metode rolplaying dalam pembelajaran pendidikan kewarganegaraan materi dampak globalisasi pada siswa kelas IV SD Negeri 4 Gunung Rajak. Tepat untuk dipertahankan dalam rangka peningkatan prestasi siswa pada siklus kedua.

Sesuai dengan harapan peneliti bahwa hasil belajar siswa akan dapat meningkat pada siklus berikutnya, maka perlu mendapat perbaikan pada penekanan proses pemahaman konsep untuk mencapai hasil belajar yang lebih dengan memantapkan tahapan - tahapan pelaksanaan penggunaan metode rle playing.

\section{Deskripsi Analisis Hasil Penelitian Tindakan Siklus II}

\section{Perencanaan.}

1. Merancang tekhnik yang akan dilakukan dalam pembelajaran .

2. Menyiapkan alat dan bahan yang akan dipergunakan.

3. Membuat instrument penilaian

4. Mempersiapkan lembar observasi dan pengamatan.

5. Merancang tekhnik penilaian. 


\section{Pelaksanaan tindakan.}

Pada tahap kegiatan pembelajaran PKn dengan menerapkan model pembelajaran Role Playing meliputi beberapa tahapan sebagai berikut:

Kegiatan Awal

a. Guru mengkondisikan kelas untuk memulai kegiatan pembelajaran.

b. Guru menyampaikan apersepsi: memotivasi, dan menjelaskan tujuan pembelajaran yang akan dicapai melalui kegiatan pembelajaran model role playing

c. Guru memotivasi siswa untuk belajar dengan mengaitkan materi yang akan dipelajari dengan materi yang telah lalu.

Kegiatan Inti:

a. Guru memberikan penjelasan tentang materi Dampak Globalisasi. Pada tahap ini siswa dihadapkan pada sesuatu yang menimbulkan kebingungan dan mereka dirangsang untuk melakukan kegiatan bermain peran guna menjawab kebingungan tersebut.

b. Guru memberi kesempatan kepada peserta didik untuk mengidentifikasi sebanyak mungkin masalah yang relevan dengan bahan pelajaran, kemudian salah satunya dipilih dan dirumuskan dalam bentuk bermain peran..

c. Ketika eksplorasi berlangsung, guru memberi kesempatan kepada para peserta didik untuk mengumpulkan informasi sebanyak-banyaknya yang relevan untuk membuktikan benar atau tidaknya hipotesis.

d. Kemudian guru mengolah data dan informasi yang telah diperoleh para peserta didik baik melalui wawancara, observasi, dan sebagainya.

e. Siswa melakukan pemeriksaan secara cermat untuk membuktikan benar atau tidaknya hipotesis yang ditetapkan 
dengan temuan alternatif, dihubungkan dengan hasil pengolahan data.

f. Siswa menarik kesimpulan yang dapat dijadikan prinsip umum dan berlaku untuk semua kejadian atau masalah yang sama dengan memperhatikan hasil pembuktian.

g. Guru memberi penguatan dan memberi motivasi terhadap siswa agar lebih berani dalam mengutarakan pendapatnya.

h. Siswa diberi kesempatan untuk bertanya tentang materi yang belum dipahami.

i. Guru membagikan soal tes formatif mengenai materi yang telah diberikan.

Kegiatan Akhir

a. Guru bersama-sama siswa menyimpulkan materi yang telah dipelajari.

b. Guru memberikan motivasi kepada siswa agar selalu rajin belajar.

c. Guru memberikan tindak lanjut berupa PR untuk mengetahui tingkat kepahaman siswa.

d. Sebelum mengakhiri pembelajaran, guru mengajak para siswa berdoa sebagai penutup pembelajaran hari ini.

Data hasil prestasi belajar siswa dapat dilihat dalam tabel berikut ini :

Tabel 2.1 Perolehan / prestasi belajar pada siklus II

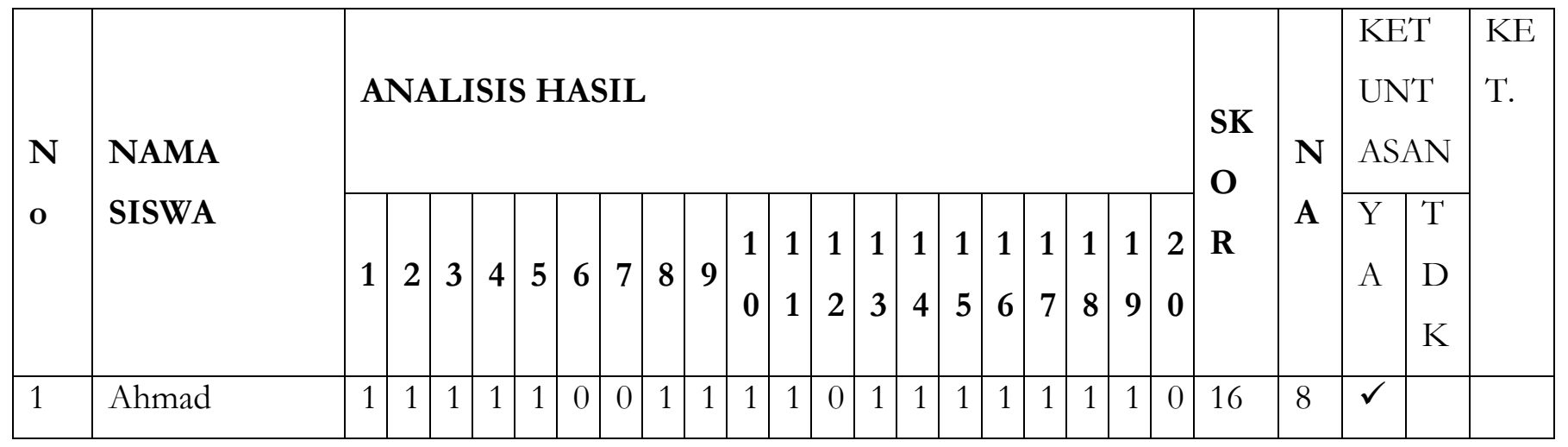




\begin{tabular}{|c|c|c|c|c|c|c|c|c|c|c|c|c|c|c|c|c|c|c|c|c|c|c|c|c|c|}
\hline & Amtohyi & & & & & & & & & & & & & & & & & & & & & & 0 & & \\
\hline 2 & Ahmad Riandi & 1 & 1 & 1 & 1 & 1 & 1 & 0 & 1 & 1 & 1 & 1 & 0 & 1 & 1 & 1 & 1 & 1 & 0 & 0 & 0 & 15 & $\begin{array}{l}7 \\
5\end{array}$ & $\checkmark$ & \\
\hline 3 & $\begin{array}{ll}\text { Aidil } & \text { Majdi } \\
\text { Azrori } & \end{array}$ & 1 & 1 & 1 & 0 & 1 & 1 & 1 & 1 & 1 & 1 & 1 & 0 & 1 & 1 & 0 & 1 & 1 & 1 & 0 & 0 & 16 & $\begin{array}{l}8 \\
0\end{array}$ & $\checkmark$ & \\
\hline 4 & Antoni Saputra & 1 & 1 & 1 & 1 & 1 & 0 & 1 & 1 & 1 & 1 & 1 & 1 & 0 & 1 & 1 & 1 & 1 & 0 & 1 & 0 & 16 & $\begin{array}{l}8 \\
0\end{array}$ & $\checkmark$ & \\
\hline 5 & Azlina Fitri & 1 & 1 & 1 & 1 & 1 & 0 & 1 & 1 & 1 & 1 & 1 & 0 & 1 & 0 & 0 & 1 & 0 & 1 & 1 & 0 & 14 & $\begin{array}{l}7 \\
0\end{array}$ & $\checkmark$ & \\
\hline 6 & $\begin{array}{l}\text { Baiq } \\
\text { Silaturrahmi }\end{array}$ & 0 & 1 & 0 & 1 & 1 & 1 & 1 & 1 & 0 & 0 & 1 & 1 & 1 & 1 & 1 & 0 & 1 & 1 & 1 & 0 & 14 & $\begin{array}{l}7 \\
0\end{array}$ & $\checkmark$ & \\
\hline 7 & Bunga Ulandari & 1 & 1 & 1 & 0 & 1 & 1 & 1 & 1 & 0 & 1 & 1 & 1 & 1 & 1 & 0 & 1 & 1 & 1 & 0 & 0 & 15 & $\begin{array}{l}7 \\
5\end{array}$ & $\checkmark$ & \\
\hline 8 & Depiana Lestari & 1 & 1 & 1 & 1 & 1 & 0 & 1 & 1 & 0 & 1 & 1 & 0 & 1 & 1 & 0 & 1 & 0 & 0 & 1 & 1 & 14 & $\begin{array}{l}7 \\
0\end{array}$ & $\checkmark$ & \\
\hline 9 & $\begin{array}{ll}\text { Fadilah Olya } \\
\text { Suganda }\end{array}$ & 1 & 1 & 1 & 1 & 1 & 0 & 1 & 1 & 1 & 1 & 1 & 1 & 1 & 1 & 1 & 1 & 0 & 1 & 1 & 1 & 18 & $\begin{array}{l}9 \\
0\end{array}$ & $\checkmark$ & \\
\hline 10 & Fuji Salwati & 1 & 1 & 1 & 1 & 1 & 1 & 1 & 1 & 1 & 0 & 0 & 1 & 0 & 1 & 0 & 1 & 0 & 1 & 0 & 1 & 14 & $\begin{array}{l}7 \\
0\end{array}$ & $\checkmark$ & \\
\hline 11 & Ikhsan Jayadi & 1 & 1 & 1 & 0 & 1 & 1 & 1 & 1 & 1 & 1 & 1 & 0 & 0 & 0 & 0 & 0 & 1 & 0 & 1 & 1 & 13 & $\begin{array}{l}6 \\
5\end{array}$ & & $\sqrt{ }$ \\
\hline 12 & $\begin{array}{l}\text { Inayatul } \\
\text { Wahidah }\end{array}$ & 1 & 1 & 1 & 1 & 1 & 0 & 1 & 1 & 0 & 1 & 1 & 0 & 1 & 1 & 1 & 1 & 1 & 1 & 1 & 1 & 17 & $\begin{array}{l}8 \\
5\end{array}$ & $\checkmark$ & \\
\hline 13 & $\begin{array}{l}\text { Indah Hairun } \\
\text { Nisa }\end{array}$ & 1 & 1 & 1 & 1 & 0 & 1 & 1 & 1 & 1 & 1 & 1 & 0 & 0 & 0 & 1 & 1 & 0 & 1 & 1 & 1 & 15 & $\begin{array}{l}7 \\
5\end{array}$ & $\checkmark$ & \\
\hline 14 & Irsan Hamdani & 1 & 1 & 0 & 0 & 1 & 1 & 1 & 1 & 1 & 1 & 1 & 0 & 1 & 0 & 1 & 1 & 0 & 1 & 1 & 0 & 14 & $\begin{array}{l}7 \\
0\end{array}$ & $\checkmark$ & \\
\hline 15 & Luna & 1 & 1 & 1 & 1 & 1 & 0 & 1 & 1 & 1 & 1 & 1 & 0 & 1 & 1 & 1 & 0 & 0 & 1 & 1 & 1 & 16 & 8 & $\checkmark$ & \\
\hline
\end{tabular}




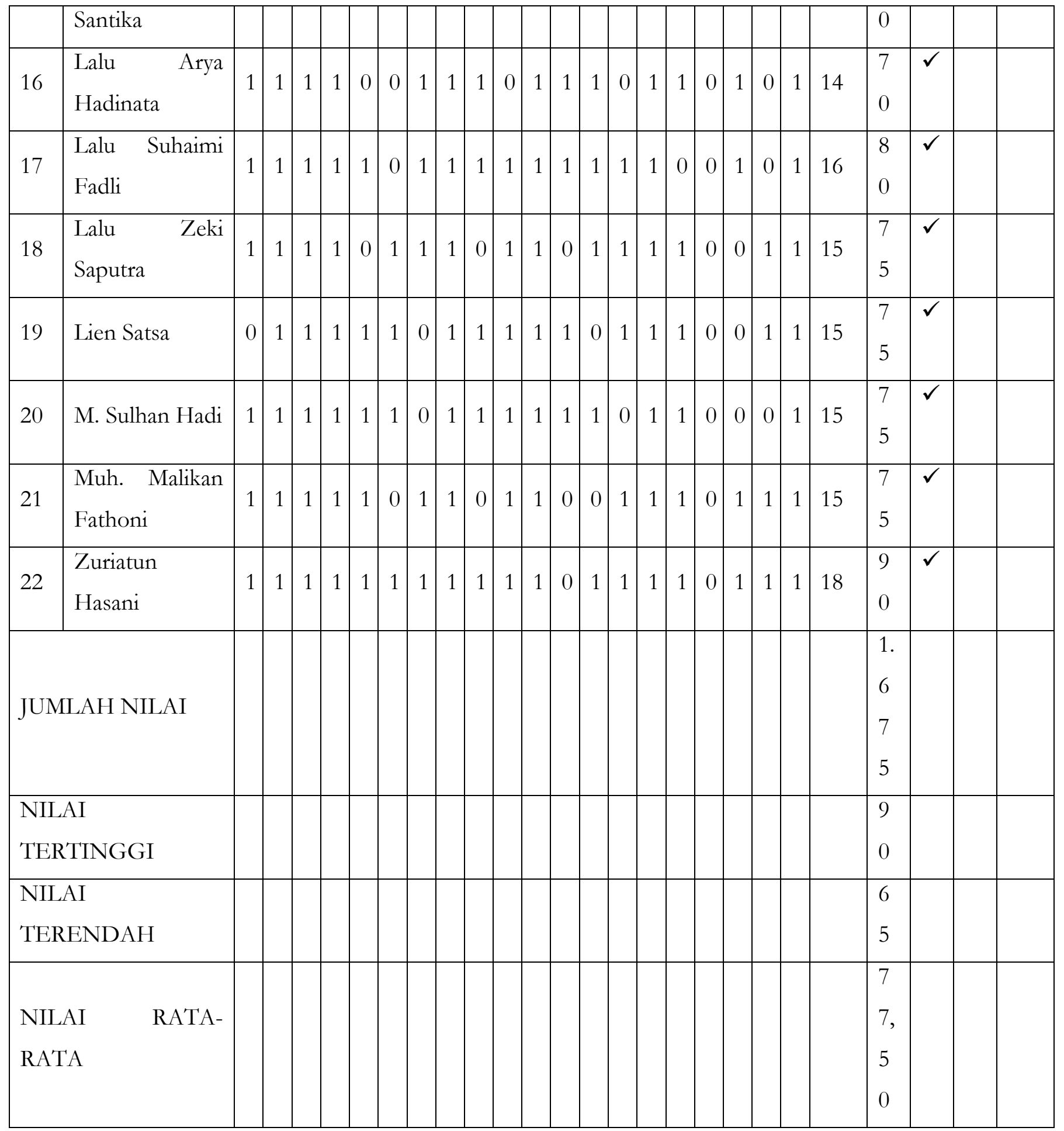




\section{Catatan Akhir}

Analisis aktivitas siswa yang diukur dari skor rata-rata aktivitas belajar dan aktivitas kerjasama menunjukkan bahwa ada peningkatan dari siklus I ke siklus II. Ratarata aktivitas siswa pada siklus I adalah 67,50 dengan klasifikasi cukup aktif dan pada siklus II adalah 77,50 dengan klasifikasi aktif, berarti mengalami peningkatan sebesar 10,00. Adanya peningkatan aktivitas siswa dalam pembelajaran ini karena siswa diberikan kesempatan yang sangat luas dalam berpartisipasi aktif saat melakukan pembelajaran, dan bermain peran.

Hasil belajar siswa yang berkaitan dengan materi dampak globalisasi ditunjukkan dengan nilai rata-rata siklus I adalah 67,50 termasuk kategori baik dan ketuntasan belajarnya adalah 65,55\%. Sedangkan nilai rata-rata siklus II adalah 77,50 termasuk kategori baik dan ketuntasan belajarnya adalah 95,45 \%.

Hasil antar siklus digambarkan dalam table berikut ini :

Tabel1.3.Perbandingan prestasi belajar pada siklus I dan II

\begin{tabular}{|l|l|l|l|l|l|}
\hline No & NamaSiswa & & Siklus I & Siklus II & Perbandingan \\
\hline 1 & Ahmad Amtohyi & 70 & 80 & 10 \\
\hline 2 & Ahmad Riandi & 65 & 75 & 10 \\
\hline 3 & Aidil Majdi Azrori & & & \\
\hline 4 & Antoni Saputra & 65 & 80 & 15 \\
\hline 5 & Azlina Fitri & 60 & 80 & 20 \\
\hline 6 & Baiq Silaturrahmi & 60 & 70 & 10 \\
\hline 7 & Bunga Ulandari & 55 & 70 & 15 \\
\hline 8 & Depiana Lestari & 70 & 75 & 5 \\
\hline 9 & Fadilah Olya Suganda & 65 & 70 & 5 \\
\hline 10 & Fuji Salwati & 80 & 90 & 10 \\
\hline 11 & Ikhsan Jayadi & 60 & 70 & 10 \\
\hline 12 & Inayatul Wahidah & 50 & 65 & 15 \\
\hline
\end{tabular}




\begin{tabular}{|l|l|l|l|l|}
\hline 13 & Indah Hairun Nisa & 70 & 75 & 5 \\
\hline 14 & Irsan Hamdani & 60 & 70 & 10 \\
\hline 15 & Julia Luna Santika & 75 & 80 & 5 \\
\hline 16 & Lalu Arya Hadinata & 65 & 70 & 5 \\
\hline 17 & Lalu Suhaimi Fadli & 75 & 80 & 5 \\
\hline 18 & Lalu Zeki Saputra & 75 & 75 & 0 \\
\hline 19 & Lien Satsa & 75 & 75 & 0 \\
\hline 20 & M. Sulhan Hadi & 70 & 75 & 5 \\
\hline 21 & Muh. Malikan Fathoni & 65 & 75 & 10 \\
\hline 22 & Zurriatun Hasani & 85 & 90 & 5 \\
\hline JUMLAH NILAI & 1.480 & 1.675 & 195 \\
\hline NILAI TERTINGGI & 85 & 90 & 20 \\
\hline NILAI TERENDAH & 50 & 65 & 5 \\
\hline \multicolumn{2}{|l|}{ RATA - RATA / \% } & 67,50 & 77,50 & 8,86 \\
\hline
\end{tabular}

\section{Daftar Rujukan}

Arikunto Suharsimi. 2006. Prosedur Penelitian: Suatu Pendekatan Praktik. Jakarta: Renika Cipta.

BNSP 2006 Standar isi Kompetensi dasar mata Pelajaran Pendidikan kewarganegaraan SD kelas $V$. Jakarta: Erlangga.

Chotimah Husnul, Dwitasari Yuyun. 2009. Strategi-strategi Pembelajaran Untuk Penelitian Tindakan Kelas. Malang: Surya Pena Gemilang.

Hamalik, Oemar. 2009. Strategi Belajar Mengajar Berdasarkan CBSA. Bandung: Sinar Baru Algensido.

http://globalisasiriva.blogspot.co.id/p/pengertian-globalisasi.html Dampak Positif Dan

Dampak Negatif Globalisasi Dan Modernisasi

http:/ tipsserbaserbi.blogspot.co.id/2015/09/pengertian-pendidikan

kewarganegaraan.html hari Selasa, 07-03-2017 pukul 09.30 
http://globalisasiriva.blogspot.co.id/p/pengertian-globalisasi.html Dampak Positif Dan Dampak Negatif Globalisasi Dan Modernisasi.

-------------, dkk. 2004. Strategi belajar Mengajar. Jakarta: Universitas Terbuka.

Rasyidi Abdul Haris. 2012. Meningkatkan Hasil Belajar Bahasa Arab dalam Materi Hiwar Melalui Strategi Pembelajaran Cooperative Learning Tipe Probelm Posing MTs NW Selebung Ketangga. Skripsi Ilmiah, Tidak Dipulikasikan.

Setiati Rahayu, dan Ningsih Fajar. 2008. PKn SD/MI kelas V. Jakarta: Pusat Perbukuan.

Suprijono Agus. 2009. Cooperative learning: Teori dan Apliksai Paikem. Yogyakarta: Pustaka Pelajar.

Winarta Putra, Udin S.dkk. 2006. Materi dan pembelajaran PKn SD. Jakarta: Universitas Terbuka. 